\title{
Dietary sodium requirement determined for juvenile hybrid tilapia (Oreochromis niloticus $\times 0$. aureus) reared in fresh water and seawater
}

\author{
Shi-Yen Shiau* and Li-Shan Lu \\ Department of Food Science, National Taiwan Ocean University, Keelung 202, Taiwan
}

(Received 11 August 2003 - Revised 16 December 2003 - Accepted 5 January 2004)

Two 8-week feeding trials were conducted to determine the dietary Na requirement for juvenile hybrid tilapia (Oreochromis niloticus $\times$ O. aureus) reared in fresh water and seawater. In each experiment, $\mathrm{NaCl}$ was added to the basal diet at $0,0 \cdot 5,1,2,3,5$, or $7 \mathrm{~g} \mathrm{Na} / \mathrm{kg} \mathrm{diet}$ (fresh water) and at $0,0 \cdot 2,0 \cdot 5,0 \cdot 8,1 \cdot 2,1 \cdot 5,2$, or $3 \mathrm{~g} \mathrm{Na} / \mathrm{kg}$ diet (seawater). Each diet was fed to three replicate groups of fish, individual fish initially weighing 0.69 (SE 0.01) g, in a closed, recirculating rearing system. In fresh water, the tilapia fed the diet supplemented with $2 \mathrm{~g} \mathrm{Na} / \mathrm{kg}$ diet had significantly $(P<0.05)$ greater weight gain than the fish fed the diets supplemented with $\geq 3$ and $\leq 0.5 \mathrm{~g} \mathrm{Na} / \mathrm{kg} \mathrm{diet}$. Feed efficiency (FE) in fish generally followed the weight-gain pattern. Gill $\mathrm{Na}^{+}-\mathrm{K}^{+}$ATPase activity was highest in the fish fed the diets supplemented with $1-3 \mathrm{~g} \mathrm{Na} / \mathrm{kg}$ diet, followed by the fish fed the diet with $7 \mathrm{~g} \mathrm{Na} / \mathrm{kg}$ diet and lowest in the fish fed the unsupplemented control diet. In seawater, the weight gain, FE and gill $\mathrm{Na}^{+}-\mathrm{K}^{+}$ATPase activity in fish were not affected by the dietary treatment. Analysis by polynomial regression of weight gain, by broken-line regression of gill $\mathrm{Na}^{+}-\mathrm{K}^{+}$ATPase activity and by linear regression of wholebody $\mathrm{Na}$ retention of the fish reared in fresh water, indicated that the adequate dietary $\mathrm{Na}$ concentration for tilapia is about $1.5 \mathrm{~g} / \mathrm{kg}$ diet. The present study also suggests that no dietary $\mathrm{Na}$ is required for tilapia reared in seawater.

Sodium: Fish: Tilapia

Tilapia are mainly lacustrine fish and are well adapted to enclosed water from low salinity (fresh water) to high salinity (seawater). They are widely cultured in tropical and subtropical regions of the world and constitute the third largest group of farmed finfish, with an annual production growth rate of about $11.5 \%$ (El-Sayed, 1999), and a future increase in production has been projected (New, 1999).

Knowledge in the area of tilapia nutrition has increased greatly in recent years. There is a need for further advancements in nutritional research as tilapia production becomes more intensive. One class of nutrients which has not been extensively studied with respect to tilapia is the minerals (Shiau, 2002).

$\mathrm{Na}$ and $\mathrm{K}$ are essential minerals in animals because of their role in electrolyte and acid-base balance; $\mathrm{Na}^{+}$is the principal extracellular cation, whereas $\mathrm{K}^{+}$is the principal intracellular cation in animal tissues. Dietary requirements for these two minerals have been reported for several land animals. However, fish are known to readily exchange these minerals across their gills in order to maintain acidbase balance and osmotic pressure with their aquatic environment. The requirement for $\mathrm{K}$ in tilapia has recently been established (Shiau \& Hsieh, 2001). The dietary requirement of $\mathrm{Na}$ in fish has only been qualitatively determined by supplementation with $\mathrm{NaCl}$ and the results vary. Dietary supplementation with $\mathrm{NaCl}$ improved the growth of common carp (Cyprinus carpio (Linn.)) and mrigal (Cirrhinus mrigala (Ham.)) (Nandeesha et al. 2000) and also the growth of red drum (Sciaenops ocellatus; Gatlin et al. 1992) in fresh-water environments. However, beneficial effects of $\mathrm{NaCl}$ supplementation on growth were not observed in Atlantic salmon (Salmo salar; Shaw et al. 1975) and rainbow trout (Oncorhynchus mykiss (MacLeod, 1978); Salmo gairdneri Richardson (Salman \& Eddy, 1988).

The purpose of the present study was to estimate the dietary $\mathrm{Na}$ requirement of juvenile tilapia (Oreochromis niloticus $\times O$. aureus) reared in fresh water and seawater using growth indices supported by the measurement of gill $\mathrm{Na}^{+}-\mathrm{K}^{+}$ATPase activity and whole-body $\mathrm{Na}$ retention.

\section{Materials and methods}

\section{Diet preparation}

The experimental diet formulation is given in Table 1 . The formulation, which has been shown to be adequate for tilapia, was similar to that used by Shiau \& Lo (2000), except that the protein content of the diet was adjusted to the optimal level required for tilapia reared in seawater (Shiau \& Huang, 1989). Vitamin-free casein (Sigma Chemical Co., St Louis, MO, USA) was used as the protein source. The mineral mixture was similar to that used by Shiau \& Hsieh (2001), except that it did not contain Na. 
(Table 2). The pattern of feed efficiency was similar to that of weight gain. Survival of fish among the dietary groups was $93-100 \%$. Gill $\mathrm{Na}^{+}-\mathrm{K}^{+}$ATPase activity was highest in the fish fed the diets supplemented with $1-3 \mathrm{~g} \mathrm{Na} / \mathrm{kg}$ diet, followed by the fish fed the diet with $7 \mathrm{~g} \mathrm{Na} / \mathrm{kg}$ diet and lowest in the fish fed the unsupplemented control diet. In the seawater-rearing environment, all these parameters were not significantly different among all the dietary groups (Table 3 ).

The weight gain of the fish reared in fresh water and their gill $\mathrm{Na}^{+}-\mathrm{K}^{+}$ATPase activity $v$. dietary Na concentration were analysed by polynomial (cubic) regression (Zeitoun et al. 1976) and broken-line analysis (Robbins, 1986), respectively. As shown in Fig. 1, the Na requirement of tilapia is estimated to be 1.9 (weight gain) and $1 \cdot 3$ (gill $\mathrm{Na}^{+}-\mathrm{K}^{+}$ATPase activity) $\mathrm{g} / \mathrm{kg}$ diet.

Whole-body $\mathrm{Na}$ concentration in the fish reared in fresh water generally increased as the dietary $\mathrm{Na}$ supplementation level increased $(Y=0 \cdot 03 X+0 \cdot 16, r 0.98$; Table 4), but this linear increase in body $\mathrm{Na}$ concentration was not observed in the fish reared in seawater (Table 5).
When these data were used to calculate the whole-body $\mathrm{Na}$ retention for each group of fish, linear regression analysis of the dietary $\mathrm{Na}$ levels $v$. whole-body $\mathrm{Na}$ retention values (Fig. 2) indicated an Na requirement of $1.3 \mathrm{~g} / \mathrm{kg}$ diet $(Y=-0.70 X+0.94, r-0.99)$ for fish reared in fresh water, whereas no dietary $\mathrm{Na}$ is required for fish reared in seawater $(Y=-0.58 X+0 \cdot 01, r-0.99)$.

\section{Discussion}

The essentiality of dietary $\mathrm{Na}$ for normal growth of tilapia in fresh water is clearly demonstrated in the present study. Weight gain was reduced for the fish given the unsupplemented basal diet and increased with incremented increases in dietary $\mathrm{Na}$ up to the requirement level. Both food and the aquatic medium can be important sources of electrolytes for euryhaline fish. The $\mathrm{Na}$ content in the rearing water of the present study ranged from 8.51 to $15.34 \mathrm{mg} / \mathrm{l}$ in fresh water and from 10.62 to $12.42 \mathrm{~g} / \mathrm{l}$ in seawater. For juvenile tilapia reared in fresh water, the addition of $\mathrm{Na}$ to the diet improved growth and feed efficiency in

Table 2. Weight gain, feed efficiency (FE), survival and gill $\mathrm{Na}^{+}-\mathrm{K}^{+}$ATPase activity of fresh-water-reared tilapia (Oreochromis niloticus $\times 0$. aureus) fed diets containing various levels of sodium*

(Mean values and standard deviations)

\begin{tabular}{|c|c|c|c|c|c|c|c|c|}
\hline \multirow{2}{*}{$\begin{array}{l}\text { Na supplementation } \\
\text { level }(\mathrm{g} / \mathrm{kg})\end{array}$} & \multicolumn{2}{|c|}{ Weight gain (\%) } & \multicolumn{2}{|c|}{ FE† (\%) } & \multicolumn{2}{|c|}{ Survival (\%) } & \multicolumn{2}{|c|}{$\begin{array}{l}\text { Gill } \mathrm{Na}^{+}-\mathrm{K}^{+} \\
\text {ATPase }(\mu \mathrm{mol} \text { inor- } \\
\text { ganic phosphate/mg } \\
\text { protein per } \mathrm{h})\end{array}$} \\
\hline & Mean & SD & Mean & SD & Mean & SD & Mean & SD \\
\hline 0 & $281^{a}$ & 11 & $0 \cdot 61^{\mathrm{a}}$ & 0.05 & 100 & 0 & $5 \cdot 03^{c}$ & 0.09 \\
\hline 0.5 & $294^{a}$ & 17 & $0.66^{\mathrm{ab}}$ & 0.01 & 93 & $8 \cdot 4$ & $4 \cdot 74^{\mathrm{bc}}$ & 0.21 \\
\hline 1 & $312^{a b}$ & 18 & $0.69^{\mathrm{ab}}$ & 0.05 & 96 & $7 \cdot 7$ & $4.05^{a}$ & 0.31 \\
\hline 2 & $330^{b}$ & 15 & $0.71^{b}$ & 0.01 & 96 & 3.9 & $4 \cdot 01^{a}$ & 0.24 \\
\hline 3 & $284^{a}$ & 8 & $0.66^{a b}$ & 0.04 & 100 & 0 & $4 \cdot 13^{a}$ & 0.35 \\
\hline 5 & $279^{a}$ & 14 & $0.62^{\mathrm{a}}$ & 0.04 & 93 & $6 \cdot 7$ & $4 \cdot 36^{\mathrm{ab}}$ & 0.26 \\
\hline 7 & $283^{a}$ & 13 & $0.62^{a}$ & 0.06 & 97 & $4 \cdot 7$ & $4 \cdot 58^{\mathrm{b}}$ & 0.10 \\
\hline
\end{tabular}

a,b,c Mean values within a column, with unlike superscript letters are significantly different $(P<0.05)$.

${ }^{*}$ Values are means of three groups of fish (initially fifteen fish per group) except for $\mathrm{Na}^{+}-\mathrm{K}^{+}$ATPase activity determination (four fish per group).

†FE $=\mathrm{g}$ weight gain/g feed consumed.

Table 3. Weight gain, feed efficiency (FE), survival and gill $\mathrm{Na}^{+}-\mathrm{K}^{+}$ATPase activity of seawater-reared tilapia (Oreochromis niloticus $\times 0$. aureus) fed diets containing various levels of sodium*

(Mean values and standard deviations)

Gill $\mathrm{Na}^{+}-\mathrm{K}^{+}$

ATPase $(\mu \mathrm{mol}$ inorganic phosphate/mg

\begin{tabular}{|c|c|c|c|c|c|c|c|c|}
\hline \multirow{2}{*}{$\begin{array}{l}\text { Na supplementation } \\
\text { level }(\mathrm{g} / \mathrm{kg})\end{array}$} & \multicolumn{2}{|c|}{ Weight gain (\%) } & \multicolumn{2}{|c|}{ FE† (\%) } & \multicolumn{2}{|c|}{ Survival (\%) } & \multicolumn{2}{|c|}{ protein per $h$ ) } \\
\hline & Mean & SD & Mean & SD & Mean & SD & Mean & SD \\
\hline 0 & 270 & 20 & 0.58 & 0.11 & 100 & 0.0 & 5.97 & 0.55 \\
\hline 0.2 & 277 & 21 & 0.59 & 0.04 & 97 & 4.7 & 5.81 & 0.30 \\
\hline $0 . \overline{5}$ & 271 & 7 & 0.58 & 0.07 & 100 & 0.0 & $6 \cdot 29$ & 0.51 \\
\hline 0.8 & 272 & 13 & 0.58 & 0.09 & 100 & 0.0 & 5.92 & 0.09 \\
\hline 1.2 & 267 & 8 & 0.57 & 0.10 & 93 & $6 \cdot 6$ & 6.07 & 0.69 \\
\hline $1 . \overline{5}$ & 280 & 15 & 0.61 & 0.06 & 100 & 0.0 & 5.91 & 0.28 \\
\hline 2 & 266 & 19 & 0.58 & 0.08 & 96 & $3 \cdot 8$ & 5.69 & 0.78 \\
\hline 3 & 272 & 18 & 0.58 & 0.11 & 100 & 0.0 & 5.87 & 0.08 \\
\hline
\end{tabular}

*Values are means of three groups of fish (initially fifteen fish per group) except for $\mathrm{Na}^{+}-\mathrm{K}^{+}$ATPase activity determination (four fish per group). $\mathrm{TFE}=\mathrm{g}$ weight gain $/ \mathrm{g}$ feed consumed. 


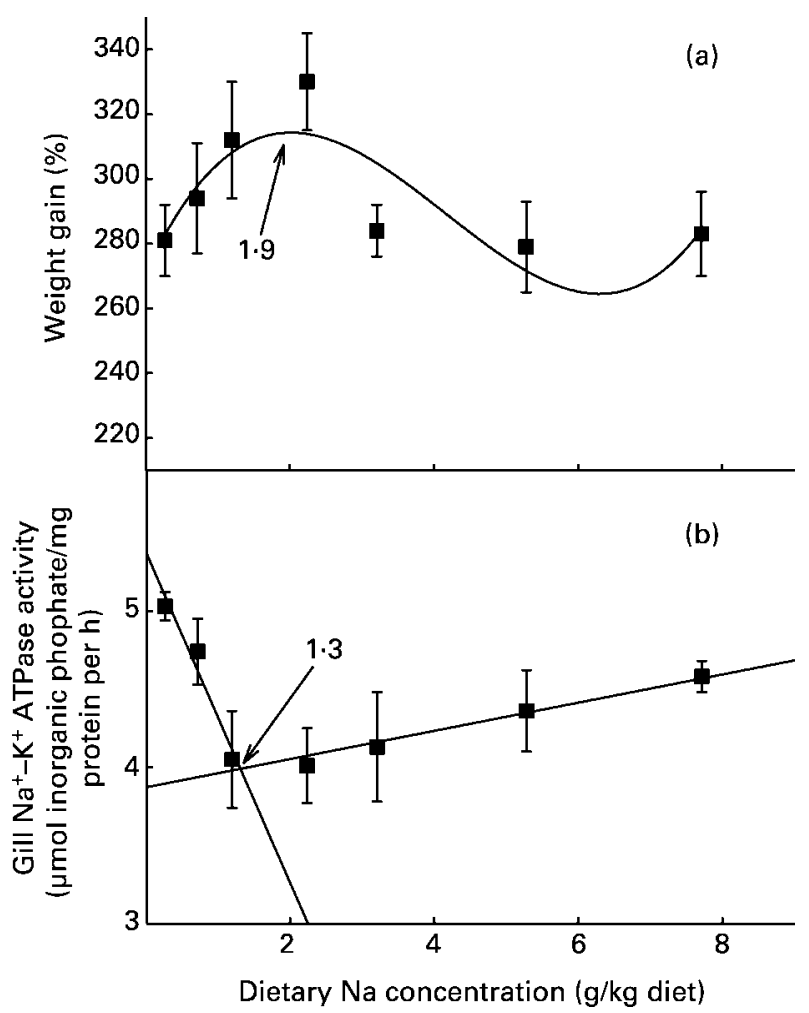

Fig. 1. The effect of dietary $\mathrm{Na}$ on relative weight gain (a) and gill $\mathrm{Na}^{+}-\mathrm{K}^{+}$ATPase activity (b) of tilapia (Oreochromis niloticus $\times 0$. aureus) reared in fresh water. For details of diets, see Table 1 and for details of procedures, see p. 586. For weight gain, each point represents the mean of three groups of fish (initially fifteen fish per group); for $\mathrm{Na}^{+}-\mathrm{K}^{+}$ATPase activity determination, each point represents the mean of three groups of fish (four fish per group). The vertical bars represent standard deviations. Requirements derived with the polynomial regression method for weight gain and with the broken-line regression method for gill $\mathrm{Na}^{+}-\mathrm{K}^{+}$ATPase are 1.9 and $1.3 \mathrm{~g} / \mathrm{kg}$ diet, respectively. For weight gain $Y=1.51 X^{3}$ $17 \cdot 84 X^{2}+52 \cdot 75 X+268 \cdot 74, r 0.81$. For gill $\mathrm{Na}^{+}-\mathrm{K}^{+}$ATPase activity $Y=-1.06 X+5.38, r-0.97 ; Y=0.10 X+3.85, r 0.96$.

the present study. However, no such benefit was apparent for the fish in seawater.

Zeitoun et al. (1976) have suggested the use of polynomial regression analysis as a means of estimating the relationship between weight gain and essential nutrient intake. As indicated by Zeitoun et al. (1976), the value corresponding to maximal gain estimated by cubic regression is defined as the maximum concentration of dietary nutrient that produces optimal growth, and beyond which growth is depressed. In the present study, the weight gain of fish reached a maximum at $2 \mathrm{~g} \mathrm{Na}$ supplementation $/ \mathrm{kg}$ diet and decreased thereafter. Thus, the requirement was estimated by a polynomial regression analysis (Zeitoun et al. 1976).

Requirements for macronutrients such as protein, lipid, and essential amino acids of cultured fish are generally best defined in growing animals by growth data in feeding studies. Besides the growth parameters, attention has been drawn to the usefulness of tissue enzyme activity measurements as an adjunct to requirement studies in that they provide a functional measure of the nutritional status of a fish (Cowey, 1976). Gills are the most important extra-renal organs responsible for osmoregulation in fish. The biochemical mechanisms for the maintenance of constant levels of ions in body fluids depend on the activity of $\mathrm{Na}^{+}-\mathrm{K}^{+}$ATPase, and the activities of gill $\mathrm{Na}^{+}-\mathrm{K}^{+}$ ATPase in euryhaline teleosts are affected by environmental salinities and ion concentrations (Hwang et al. 1989; Mayer-Gostan \& Naon, 1992; McCormick, 1995; Shiau \& Hsieh, 2001). The altered and unaffected gill $\mathrm{Na}^{+}-\mathrm{K}^{+}$ ATPase of tilapia reared in fresh water and seawater, respectively, found in the present study suggests that this variable may permit a satisfactory evaluation of $\mathrm{Na}$ status of the fish. The broken-line analysis of gill $\mathrm{Na}^{+}-\mathrm{K}^{+}$ ATPase activity in tilapia reared in fresh water (Fig. 1) suggests that gill $\mathrm{Na}^{+}-\mathrm{K}^{+}$ATPase activity can be used to estimate the $\mathrm{Na}$ requirement of fish.

To the best of our knowledge, the present study is the first to establish the dietary $\mathrm{Na}$ requirement in fish. Several studies with euryhaline fish have indicated that dietary salt $(\mathrm{NaCl})$ supplementation has negligible or even negative effects on growth and feed efficiency. Shaw et al. (1975) fed smolts of Atlantic salmon diets containing 4, 6 and $9 \% \mathrm{NaCl}$ in fresh water and 4,6 and $12 \% \mathrm{NaCl}$ in seawater without observing any differences in fish growth or feed efficiency among treatments. MacLeod (1978) fed

Table 4. Whole-body sodium balance of fresh-water-reared tilapia (Oreochromis niloticus $\times 0$. aureus) fed diets containing various levels of sodium*

(Mean values and standard deviations)

\begin{tabular}{|c|c|c|c|c|c|c|c|c|c|}
\hline \multirow{2}{*}{$\begin{array}{l}\text { Na supplementation } \\
\text { level ( } / \mathrm{kg} \text { diet) }\end{array}$} & \multirow{2}{*}{$\begin{array}{l}\text { Initial whole-body } \\
\text { Na concentration } \\
\text { (mg/g) }\end{array}$} & \multicolumn{2}{|c|}{$\begin{array}{l}\text { Total Na fed } \\
(\mathrm{mg} / \mathrm{g})\end{array}$} & \multicolumn{2}{|c|}{$\begin{array}{c}\text { Final whole-body } \\
\text { Na concentration } \\
\text { (mg/g) }\end{array}$} & \multicolumn{2}{|c|}{$\begin{array}{c}\text { Final-initial } \\
\text { whole-body } \mathrm{Na} \\
\text { concentration } \\
(\mathrm{mg} / \mathrm{g})\end{array}$} & \multicolumn{2}{|c|}{$\begin{array}{l}\text { Whole-body Na } \\
\text { retention† }(\mathrm{mg} / \mathrm{g})\end{array}$} \\
\hline & & Mean & SD & Mean & SD & Mean & SD & Mean & SD \\
\hline 0 & 0.23 & 0.22 & 0.02 & $1 \cdot 18$ & 0.07 & 0.95 & 0.01 & 0.72 & 0.02 \\
\hline 0.5 & 0.23 & 0.53 & 0.05 & $1 \cdot 16$ & 0.09 & 0.93 & 0.02 & 0.41 & 0.01 \\
\hline 1 & 0.23 & 0.84 & 0.05 & $1 \cdot 21$ & 0.12 & 0.98 & 0.03 & 0.14 & 0.00 \\
\hline 2 & 0.23 & 1.52 & 0.08 & 1.24 & 0.08 & 1.01 & 0.02 & -0.51 & 0.02 \\
\hline 3 & 0.23 & 2.51 & 0.12 & 1.29 & 0.13 & 1.06 & 0.03 & -1.46 & 0.03 \\
\hline 5 & 0.23 & 3.79 & 0.09 & 1.33 & 0.12 & $1 \cdot 10$ & 0.04 & -2.69 & 0.03 \\
\hline 7 & 0.23 & $5 \cdot 67$ & 1.80 & 1.43 & 0.11 & 1.20 & 0.04 & -4.48 & 0.06 \\
\hline
\end{tabular}

*Values are means of three groups of fish (four fish per group).

†Final-initial whole-body $\mathrm{Na}$ concentration-total $\mathrm{Na}$ fed. 
Table 5. Whole-body sodium balance of seawater-reared tilapia (Oreochromis niloticus $\times 0$. aureus) fed diets containing various levels of sodium*

(Mean values and standard deviations)

\begin{tabular}{|c|c|c|c|c|c|c|c|c|c|}
\hline \multirow{2}{*}{$\begin{array}{l}\text { Na supplementation } \\
\text { level ( } \mathrm{g} / \mathrm{kg} \text { diet) }\end{array}$} & \multirow{2}{*}{$\begin{array}{l}\text { Initial whole-body } \\
\mathrm{Na} \text { concentration } \\
(\mathrm{mg} / \mathrm{g})\end{array}$} & \multicolumn{2}{|c|}{$\begin{array}{l}\text { Total } \mathrm{Na} \text { fed } \\
\quad(\mathrm{mg} / \mathrm{g})\end{array}$} & \multicolumn{2}{|c|}{$\begin{array}{l}\text { Final whole-body } \\
\text { Na concentration } \\
\text { (mg/g) }\end{array}$} & \multicolumn{2}{|c|}{$\begin{array}{c}\text { Final-initial } \\
\text { whole-body Na } \\
\text { concentration } \\
(\mathrm{mg} / \mathrm{g})\end{array}$} & \multicolumn{2}{|c|}{$\begin{array}{l}\text { Whole-body Na } \\
\text { retentiont }(\mathrm{mg} / \mathrm{g})\end{array}$} \\
\hline & & Mean & SD & Mean & SD & Mean & SD & Mean & SD \\
\hline 0 & 1.44 & 0.12 & 0.01 & 1.37 & 0.10 & -0.07 & 0.00 & -0.19 & 0.01 \\
\hline 0.2 & 1.44 & 0.25 & 0.01 & 1.44 & 0.13 & 0.00 & 0.00 & -0.25 & 0.02 \\
\hline 0.5 & 1.44 & 0.42 & 0.01 & 1.46 & 0.15 & 0.02 & 0.00 & -0.40 & 0.02 \\
\hline 0.8 & 1.44 & 0.58 & 0.03 & 1.44 & 0.09 & 0.00 & 0.00 & -0.58 & 0.03 \\
\hline 1.2 & 1.44 & 0.80 & 0.02 & 1.42 & 0.16 & -0.02 & 0.00 & -0.82 & 0.02 \\
\hline 1.5 & 1.44 & 0.95 & 0.03 & 1.45 & 0.12 & 0.01 & 0.00 & -0.94 & 0.04 \\
\hline 2 & 1.44 & 1.26 & 0.02 & 1.40 & 0.08 & -0.04 & 0.00 & -1.30 & 0.04 \\
\hline 3 & 1.44 & 1.85 & 0.03 & 1.42 & 0.13 & -0.02 & 0.00 & -1.87 & 0.06 \\
\hline
\end{tabular}

*Values are means of three groups of fish (four fish per group).

†Final-initial whole-body $\mathrm{Na}$ concentration-total $\mathrm{Na}$ fed.

practical diets supplemented with $\mathrm{NaCl}$ at 5 and $8.5 \%$ to rainbow trout in fresh water and did not observe any effects on feed efficiency. In a similar study, Salman \& Eddy (1988) noted that additions of $\mathrm{NaCl}$ at 4.5, 9.2, and

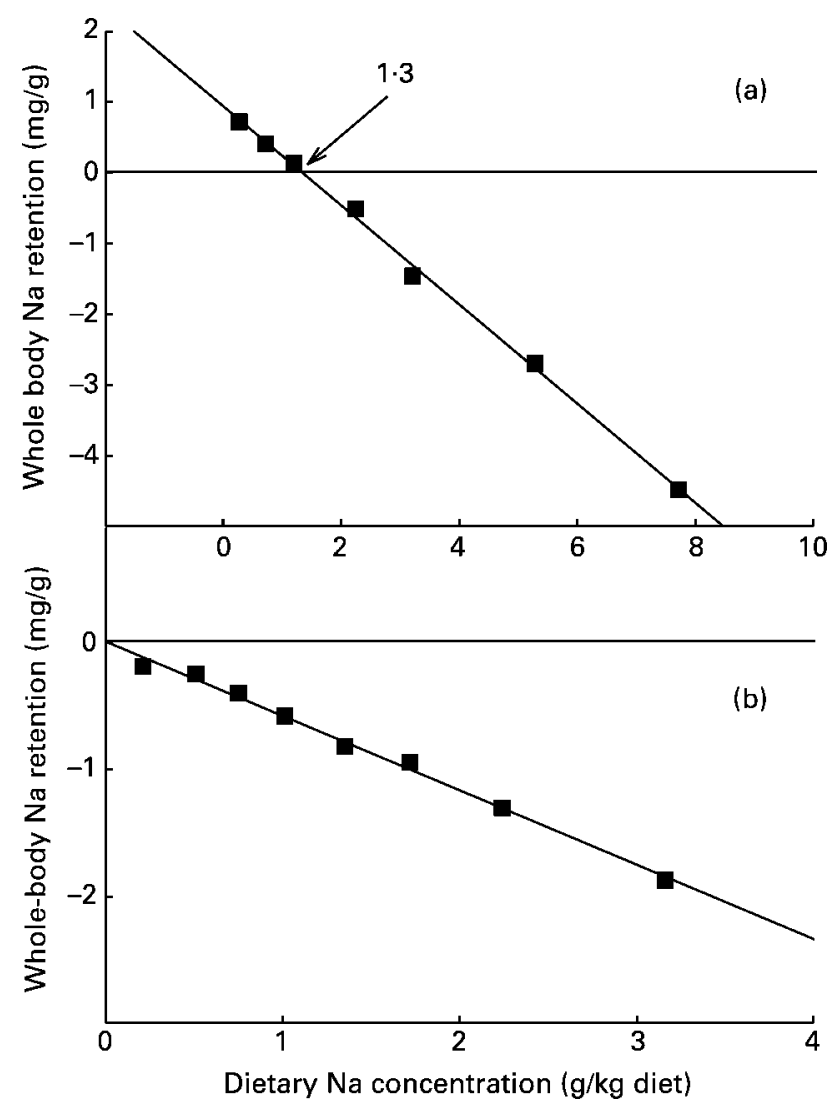

Fig. 2. The relationship between dietary $\mathrm{Na}$ concentration and whole-body Na retention in tilapia (Oreochromis niloticus $\times 0$. aureus) reared in fresh water (a) and seawater (b). For details of diets, see Table 1 and for details of procedures, see p. 586. Each point represents the mean of three groups of fish (four fish per group). The linear regression method suggests that $95 \%$ of $Y_{\max }$ in this function is achieved with a dietary Na concentration of $1.3 \mathrm{~g} / \mathrm{kg}$ diet, indicating the requirement for tilapia reared in fresh water (a), whereas no dietary $\mathrm{Na}$ is required for tilapia reared in seawater (b). For fresh-water rearing $Y=-0.70 X+0.94, r-0.99$; for seawater rearing $Y=-0.58 X+0.01, r-0.99$.
$11.6 \%$ to practical diets adversely affected growth and feed efficiency of rainbow trout in fresh water. In the present study, Na was incorporated into basal diets at $0 \cdot 5,1,2$, 3,5 , and $7 \mathrm{~g} / \mathrm{kg}$ diet for tilapia reared in fresh water; these values are equivalent to $0.127,0.254,0.509,0.763,1.272$, and $1.780 \%$ of $\mathrm{NaCl}$ level, respectively. The optimal dietary $\mathrm{Na}$ supplementation level of $1.6 \mathrm{~g} / \mathrm{kg}$ diet (equivalent to $0.406 \%$ of $\mathrm{NaCl}$ ) obtained in the present study may suggest that the $\mathrm{NaCl}$ supplementation levels used in these previous studies were too high.

Murray \& Andrews (1979) found no effects on growth for channel catfish (Ictalurus punctatus) in fresh water fed a basal diet (with $0.06 \% \mathrm{Na}$ ) supplemented with $\mathrm{NaCl}$ at 0.25 to $2.0 \%$. Note, however, that Murray \& Andrews' (1979) study was also not designed for the quantification of dietary Na requirement of channel catfish. Nevertheless, when the total $\mathrm{Na}$ content of the $0.25 \% \mathrm{NaCl}$ group in that study was calculated, a value of $1.583 \mathrm{~g} \mathrm{Na} / \mathrm{kg}$ diet (i.e. $0.983 \mathrm{~g} \mathrm{Na} / \mathrm{kg}$ of the supplementation plus $0.6 \mathrm{~g} \mathrm{Na} / \mathrm{kg}$ from the original basal diet) was obtained. This value is close to the optimal dietary $\mathrm{Na}$ requirement of tilapia (i.e. $1.6 \mathrm{~g} \mathrm{Na} / \mathrm{kg} \mathrm{diet)}$ obtained in the present study. Not all fish respond well in growth rate to the dietary minerals. For example, the dietary $\mathrm{K}$ requirement of tilapia was quantified based on the weight gain of the fish (Shiau \& Hsieh, 2001). However, a study with channel catfish showed that the weight gain of the fish did not respond to the dietary K supplementation (Wilson \& El Naggar, 1992). The dietary $\mathrm{K}$ requirement of channel catfish was thus obtained by whole-body $\mathrm{K}$ retention. In the present study, as well as using the weight gain of the fish and their gill $\mathrm{Na}^{+}-\mathrm{K}^{+}$ ATPase activity to estimate the dietary $\mathrm{Na}$ requirement in tilapia, whole-body $\mathrm{Na}$ retention data were also calculated to estimate the requirement, and the values from the three variables agree well (Figs. 1 and 2).

\section{Acknowledgements}

This work was supported by a grant from the National Science Council of the Republic of China, grant number NSC 90-2313-B-019-020. 


\section{References}

Association of Official Analytical Chemists (1995) Official Methods of Analysis, 16th ed. Arlington, VA, AOAC.

Chou BS \& Shiau SY (1999) Both n-6 and n-3 fatty acids are required for maximal growth of juvenile hybrid tilapia. North Am J Aquacult 61, 13-20.

Cowey CB (1976) Use of synthetic diets and biochemical criteria in the assessment of nutrient requirement of fish. J Fish Res Board Can 33, 1040-1045.

El-Sayed AFM (1999) Alternative dietary protein sources for farmed tilapia, Oreochromis spp. Aquaculture 179, 149-168.

Gatlin DM, MacKenzie DS, Craiz SR \& Neill WH (1992) Effects of dietary sodium chloride on red drum juveniles in waters of various salinities. Prog Fish-Cult 54, 220-227.

Hwang PP, Sun CM \& Wu SM (1988) Characterization of gill $\mathrm{Na}^{+}-\mathrm{K}^{+}$-activated adenosine triphosphate from tilapia Oreochromis mossambicus. Bull Inst Zool Acad Sinica 27, 49-56.

Hwang PP, Sun CM \& Wu SM (1989) Changes of plasma osmolality, chloride concentration and gill $\mathrm{Na}^{+}-\mathrm{K}^{+}$-ATPase activity in tilapia Oreochromis mossambicus during seawater acclimation. Mar Biol 100, 295-299.

McCormick SD (1995) Hormonal control of gill $\mathrm{Na}^{+}-\mathrm{K}^{+}$-ATPase and chloride cell function. In Fish Physiology, pp. 285-315 [CM Wood and TJ Shuttleworth, editors]. vol. XIV, New York, NY: Academic Press.

MacLeod MG (1978) Relationship between dietary sodium chloride, food intake and food conversion in the rainbow trout. $J$ Fish Biol 13, 73-78.

Mayer-Gostan N \& Naon R (1992) Effects of ambient ion concentrations on gill ATPase in fresh water eel, Anguilla anguilla. Fish Physiol Biochem 10, 75-89.

Murray MW \& Andrews JW (1979) Channel catfish: the absence of an effect of dietary salt on growth. Prog Fish-Cult 41, $155-156$.
Nandeesha MC, Gangadhar B, Keshavanath P \& Varghese TJ (2000) Effect of dietary sodium chloride supplementation on growth, biochemical composition and digestive enzyme activity of young Cyprinus carpio (Linn.) and Cirrhinus mrigala (Ham.). J Aquacult Trop 15, 135-144.

New MB (1999) Global aquaculture: current trends and challenges for the 21st century. World Aquaculture 30, 8-13, 74-79.

Robbins KR (1986) A Method, SAS Program, and Example for Fitting the Broken Line to Growth Data. University of Tennessee Agricultural Experiment Station Research Report: Knoxville, TN, University of Tennessee.

Salman NA \& Eddy FB (1988) Effect of dietary sodium chloride on growth, food intake and conversion efficiency in rainbow trout (Salmo gairdneri Richardson). Aquaculture 70, 131-144.

Shaw HM, Saunders RL, Hall HC \& Henderson EB (1975) Effect of dietary sodium chloride on growth of Atlantic salmon (Salmo salar). J Fish Res Board Can 32, 1813-1819.

Shiau SY (2002) Tilapia, Oreochromis spp. In Nutrient Requirements and Feeding of Finfish for Aquaculture, pp. 273-292 [CD Webster and CE Lim, editors]. CABI Publishing. New York, NY.

Shiau SY \& Hsieh JF (2001) Quantifying the dietary potassium requirement of juvenile hybrid tilapia (Oreochromis niloticus $\times$ O. aureus). Br J Nutr 85, 213-218.

Shiau SY \& Huang SL (1989) Optimal dietary protein level for hybrid tilapia (Oreochromis niloticus $\times O$. aureus) reared in seawater. Aquaculture 81, 119-127.

Shiau SY \& Lo PS (2000) Dietary choline requirements of juvenile hybrid tilapia, Oreochromis niloticus $\times$ O. aureus. J Nutr 130, 100-103.

Wilson RP \& El Naggar G (1992) Potassium requirement of fingerling channel catfish, Ictalurus purtatus. Aquaculture 108, $169-175$.

Zeitoun IH, Ullrey DE \& Magee WT (1976) Quantifying nutrient requirement of fish. J Fish Res Board Can 33, 167-172. 